\title{
Incorporating e-learning as a tool for medical education in India: Investigating student perspectives
}

\author{
Bijli Nanda ${ }^{1, *}$, Manasi Bhattacharjee ${ }^{2}$, Omna Chawla ${ }^{3}$, Rajajeyakumar $\mathbf{M}^{4}$, Raj Kapoor ${ }^{5}$ \\ ${ }^{1}$ Associate Professor, Dept. of Physiology, SMS\&R, Greater Noida, Uttar Pradesh, ${ }^{2}$ Associate Professor, Dept. of Physiology, \\ ${ }^{5}$ Director Professor, Vardhman Mahavir Medical College \& Safdarjung Hospital, New Delhi, ${ }^{3}$ Associate Professor, Gian Sagar \\ Medical College and Hospital, Banur, Punjab, ${ }^{4}$ Assistant Professor, Chennai Medical College and Hospital, Irungalur, Trichy, \\ Tamil Nadu, India
}

*Corresponding author:

Email id: bijli.nanda@sharda.ac.in

\begin{abstract}
Aim: The undergraduate medical curriculum in India as designed by the medical council of India (MCI) currently does not include E-learning as part of its program. Although, students seem to be quite comfortable with the use of computers and internet, their perception about e-learning per se needs to be addressed. Moreover, before introduction of specific technology opinion of the user must be investigated. Hence, this study was designed with an aim to find out the Indian students perspectives regarding the incorporation of E- learning into the medical curriculum.

Materials and Methods: Undergraduate $1^{\text {st }}$ and $2^{\text {nd }}$ semester medical student volunteers were recruited for the study from 4 medical colleges from different regions of India after taking informed consent. Responses (based on a Likert scale of 1-5) were collected via a predesigned self-administered questionnaire. Positive attitudinal scores (PAS) were calculated using 7 variables. The results were analysed using SPSS

Results: A total of 775 responses were available for analysis. Median PAS was 24 indicating a positive attitude amongst students. $94.27 \%$ of students felt that E-learning should be incorporated into the curriculum. The most preferred mode of elearning was videos $(56.9 \%)$.With respect to internet usage, the majority of students $(65 \%)$ opted for a web supplemented programme compared to fully online or web independent programmes.

Conclusion: Overall Indian medical undergraduate students seem comfortable with computer use and most students perceive Elearning as a helpful tool in their learning process. Most are willing to have it incorporated into the curriculum; hence we propose that E-learning should be formally introduced into the curriculum as soon as possible.
\end{abstract}

Keywords: E-learning, Undergraduate medical curriculum, Positive attitude.

\section{Introduction}

The guidelines for undergraduate MBBS teaching laid down by the Medical Council of India propose that didactic lectures should not comprise more than $1 / 3^{\text {rd }}$ of the schedule and the rest should be in the form of group discussions, tutorials and other interactive modes of teaching. ${ }^{1}$ However, the traditional lecture-based system still forms the mainstay of teaching undergraduate medical students, with both faculty and students stressing maximum on lectures, consciously or subconsciously.

A useful supplement to conventional lecture-based teaching in the medical curriculum are e-resources. ${ }^{2} \mathrm{E}$ learners have shown increased retention rates and better utilization of content, resulting in better achievement of knowledge, skills, and attitudes. ${ }^{3}$ While information and access to information in medical science is growing steadily, there is a vast shortage of medical faculty in medical schools across the world. As a result, some schools are looking to E-learning to improve access to medical education. ${ }^{4}$ With the mushrooming of private medical colleges in India, currently there is a shortage of faculty in India too. At present, both faculty and students use E-learning in their own ways, though it is not yet a part of the formal curriculum. However, soon medical schools would need to incorporate E-learning into the curriculum, for maximum benefit.

With the integration of E-learning into medical education, educators will no longer serve as the primary distributors of content, but will become more involved as facilitators of learning and assessors of competency, promoting a shift towards adult learning theory. ${ }^{5}$ However, E-learning solutions do not come in a "one size fits all" package that will work in all settings. Introduction of new technology usually creates tension and e learning will be no exception. ${ }^{6}$ The challenge when implementing E-learning is to ensure that it takes into consideration local context and accounts for specific instructional needs before integration. ${ }^{7}$

Acceptance of E-learning has been determined to depend on many factors- computer ownership, prior experience and perception of students about E-learning ${ }^{8}$ age, gender, previous computer use, technology acceptance and individual learning styles. ${ }^{9}$ Moreover, it has been suggested that a person's intention to use any kind of technology is determined by its perceived usefulness and ease of use [TAM (technology acceptance model) $]^{10}$ and individuals are more likely to use new technology if they feel that it will enhance their performance. ${ }^{11}$ It is imperative to understand students' perception about E-learning before implementing and 
developing a successful E-learning environment. ${ }^{12}$ Hence, we aimed to understand the students' perspectives regarding the incorporation of E-learning into the medical curriculum in our country by designing a questionnaire based study.

\section{Aim}

To understand student perspectives, regarding the incorporation of E-learning into the medical curriculum.

\section{Materials and Methods}

Medical Students across all years of medical school were recruited from 4 medical colleges across the country ( 3 from northern India and one from southern India). Verbal or informed consent was taken from the students as per recommendation of the ethical committee of respective institutes and the participants were provided with a questionnaire (appendix 1) to assess the perceived advantages and disadvantages of incorporating E-learning into the medical curriculum. The questionnaire had two parts. The first part consisted of subject details like age, sex etc. and questions on computer and internet usage along with awareness of E-learning (Appendix1, page1). The second part was given after students had filled the first part. This consisted of a definition of E-learning followed by questions on perceptions regarding the use of E-learning in undergraduate medical teaching. All responses were collected based on the 5-point Likert scale. Students were asked not to mention their names and leave the questionnaires (filled/not filled) on a table. The questionnaires were collected later in order to maintain student privacy. The data was later statistically analysed using SPSS.version16.

Pearson's Chi-square test was used to look for any gender differences in computer usage and for gender differences in awareness of E-learning

Positive Attitudinal scores were calculated by compiling responses to 7 questions (E-learning system will be easy to use, E-learning will save time, It will make learning easier, it will make course content easier to understand, I will be more motivated, It will give me more independence, It will increase my learning efficiency). Individual scale value for each item was added and median was calculated. Mann Whitney-U test was used to look for any gender differences in positive attitudinal scores.
Responses were analysed to see what percentage of students favoured incorporation of E-learning into the curriculum. Pearson Chi-square test was conducted to measure the association between use of computer by the students and whether they felt that E-learning should be incorporated into curriculum. The Kruskal Wallis test was used to look for differences between the positive attitudinal scores across different years in medical school.

Chi-square analysis was done to look for any significant gender differences in positive attitude/ towards E-learning.

\section{Results}

A total of 775 questionairres were included in the study.33 questionnaires were incomplete and hence were disregarded. Most of the students $(92.5 \%$ of males and $93.5 \%$ of females) had been using a computer/laptop for more than 5 years (Fig. I). There were no significant gender differences in computer usage or in the awareness of E-learning.

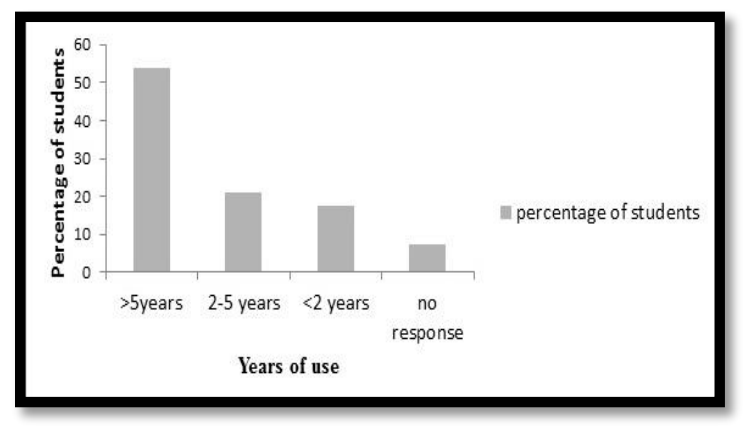

Fig. I: Years of computer usage among students (bars represent percentage of students)

Table I shows the frequency of responses of students to the various questions used to calculate the positive attitudinal scores. The positive attitudinal score (PAS) showed a high overall reliability, with a Cronbach's alpha of 0.82 . Median PAS was 24 indicating a positive attitude amongst students. Males had a significantly higher $(\mathrm{p}=0.02)$ positive attitudinal score (median $=24$, Mean rank=376) compared to females (Median=23, mean rank= 339).A significant difference was observed in the positive attitudinal scores of students towards E-learning across different years with students in the fourth year having the highest scores (Table II). 
Table I: Effect of E-learning on learning process (results expressed as number of students with percentages in brackets)

\begin{tabular}{|l|c|c|c|c|c|}
\hline & $\begin{array}{l}\text { Strongly } \\
\text { disagree }\end{array}$ & Disagree & $\begin{array}{c}\text { Neither Agree } \\
\text { not Disagree }\end{array}$ & Agree & $\begin{array}{c}\text { Strongly } \\
\text { Agree }\end{array}$ \\
\hline $\begin{array}{l}\text { Will be Easy to } \\
\text { Use }\end{array}$ & $7(0.9 \%)$ & $11(1.4 \%)$ & $127(16.3 \%)$ & $367(47.2 \%$ & $253(32.5 \%)$ \\
\hline Will Save time & $13(1.7 \%)$ & $32(4.1 \%)$ & $173(22.2 \%)$ & $370(47.6 \%)$ & $175(22.6 \%)$ \\
\hline $\begin{array}{l}\text { Learning will be } \\
\text { easier }\end{array}$ & $7(0.9 \%)$ & $24(3.1 \%)$ & $110(14.1 \%)$ & $382(49.1 \%)$ & $222(28.5 \%)$ \\
\hline $\begin{array}{l}\text { Understanding } \\
\text { will be better }\end{array}$ & $8(1 \%)$ & $31(4 \%)$ & $109(14 \%)$ & $394(51 \%)$ & $217(27.9 \%)$ \\
\hline $\begin{array}{l}\text { Will Increase } \\
\text { Learning } \\
\text { efficiency }\end{array}$ & $5(0.6 \%)$ & $40(5.1 \%)$ & $172(22.1 \%)$ & $363(46.7 \%)$ & $184(23.7 \%)$ \\
\hline $\begin{array}{l}\text { Will give more } \\
\text { Independence }\end{array}$ & $10(1.3 \%)$ & $32(4.1 \%)$ & $216(27.8 \%)$ & $335(43.1 \%)$ & $163(21 \%)$ \\
\hline $\begin{array}{l}\text { Will motivate } \\
\text { me }\end{array}$ & $16(2.1 \%)$ & $54(6.9 \%)$ & $227(29.2 \%)$ & $310(39.8 \%)$ & $150(19.4 \%)$ \\
\hline
\end{tabular}

Table II: Median positive attitudinal scores for students (interquartile ranges -IQR, given in brackets) with mean ranks.

\begin{tabular}{|l|c|c|c|c|}
\hline & & $\begin{array}{c}\text { Positive attitudinal } \\
\text { score median }\end{array}$ & $\begin{array}{c}\text { Mean } \\
\text { Rank }\end{array}$ & P value \\
\hline First year & 396 & 23(IQR 4) & 263.72 & \multirow{2}{*}{0} \\
\cline { 1 - 4 } Second year & 85 & 25(IQR 5) & 340.25 & \multirow{2}{*}{0.00} \\
\hline Third year & 51 & 24(IQR 4) & 278.28 & \\
\cline { 1 - 4 } Fourth year & 30 & 25(IQR 5.25) & 355.15 & \\
\cline { 1 - 3 }
\end{tabular}

$94.27 \%$ of students opined that E-learning should be incorporated into the curriculum. There was no significant association with the usage of computers.

Fig. II shows the opinion of students with respect to the percentage of course they feel should be covered by E-learning modes. The preferred modes of Elearning by students in order of preference were videos (56.9\%), Internet (37.4\%), Power point presentations $(32.5 \%)$, CDs (12\%) and intranet (6.4\%).

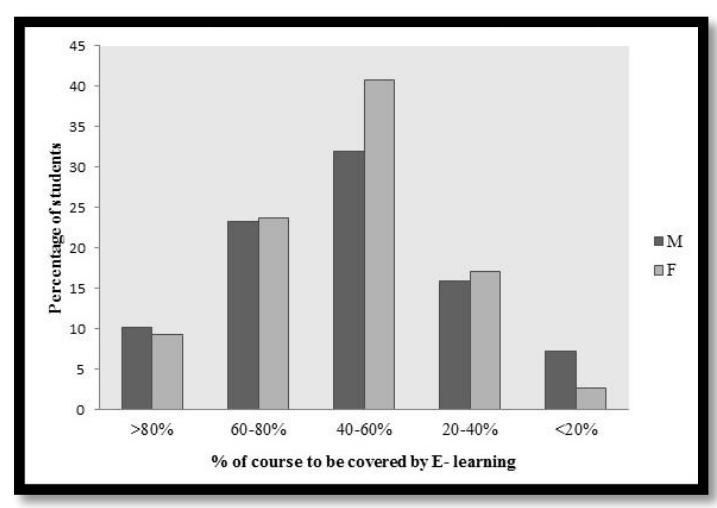

Fig. II: Students' opinion on percentage of course to be covered by E-learning (Dark bars represent opinions of males and light bars represent opinions of females)
Fig. III shows students' opinion on usage of web/internet for teaching. The most common preference was for a web supplemented program.

No significant association was observed in use of computers and preference for incorporation of Elearning into the curriculum.

A trend towards an increase in positive attitudinal scores was noted from the first year to the fourth year (Table II).

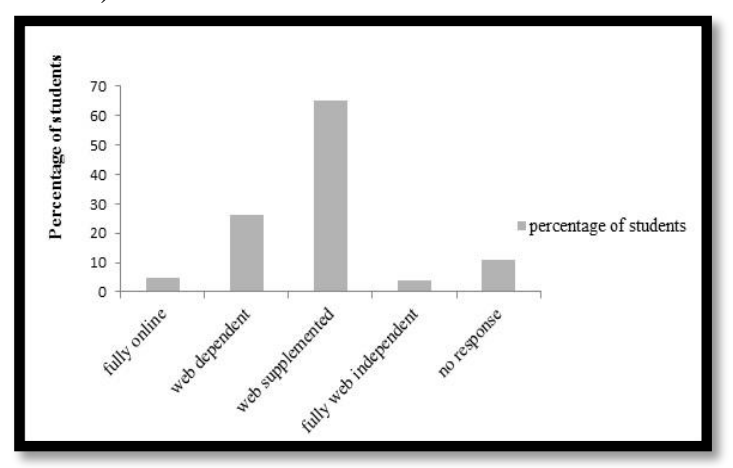

Fig. III: Preference of students for use of web-based learning

\section{Discussion}

There were no significant differences in the usage of computers across genders in our study. Awareness of E-learning was also similar amongst males and females. It is possible that students who were comfortable with 
the use of computers and internet would have a greater preference for incorporation of E-learning into the curriculum. Age, computer use, and previous exposure to computers have been found to be more important than gender with respect to attitudes towards Elearning ${ }^{13}$. However, we did not find any significant association between the use of computers and preference for incorporation of E-learning into the curriculum, possibly because all the students were quite familiar with their use.

While, owing to the wide range of computer skills among students, a single computer course for all students may not be justified, special measures need to be taken to prevent students who lack computer skills from being disadvantaged. E-learning should be at par with students' level of computer expertise so that they are not disheartened. ${ }^{13}$ In our study we took into consideration the number of hours of computer and internet use; however, we did not test computer skills amongst the students.

Medical education strives to encourage students to maintain their knowledge of medical science by becoming lifelong learners. Towards achieving this goal, they need to develop proper skills in information seeking and use of original scientific sources. ${ }^{14} \mathrm{E}$ resources are a useful supplement to conventional lecture-based teaching in the medical curriculum. ${ }^{2}$

An interesting observation was a trend towards an increase in positive attitudinal scores from the first year to the fourth year indicating that students in the fourth year were more ready to be independent learners than first year students. However, it would be presumptuous to make a judgement at this stage as the maximum numbers of participating students were from first year.

Overall our students seem to be willing to include E-learning along with web supplemented teaching resources in the curriculum.

\section{Conclusion}

Overall Indian medical undergraduate students seem comfortable with computer use and most students perceive E-learning as a helpful tool in their learning process. Most are willing to have it incorporated into the curriculum; hence we propose that E-learning should be formally introduced into the curriculum as soon as possible, from the very beginning of the course, to counteract the abysmal teacher student ratio in medical schools and to help our students to be at par with the rest of the world.

\section{Acknowledgement}

The authors acknowledge the help extended by Ms.

Divya Persai, Consultant PHFI for statistical analysis of the data presented in the paper.

\section{References}

1. http://www.mciindia.org/tools/announcement/Revised_G ME_2012.pdf. .

2. Varghese J, Faith M, Jacob M. Impact of e-resources on learning in biochemistry: first-year medical students' perceptions. BMC Med Educ. 2012;12:21. doi:10.1186/1472-6920-12-21.

3. Clark D. Psychological myths in E-learning. Med Teach. 2002;24(6):598-604. doi:10.1080/0142159021000063916.

4. Frehywot S, Vovides Y, Talib Z, et al. E-learning in medical education in resource constrained low- and middle-income countries. Hum Resour Heal. 2013;11(1):4. doi:10.1186/1478-4491-11-4.

5. Ruiz JG, Mintzer MJ, Leipzig RM. The impact of Elearning in medical education. Acad Med. 2006;81(3):207-212.

http://www.ncbi.nlm.nih.gov/pubmed/16501260.

6. Ellaway R, Masters K. AMEE Guide 32: E-learning in medical education Part 1: Learning, teaching and assessment. Med Teach. 2008;30(5):455-473. doi:10.1080/01421590802108331.

7. Johnson P, Ghebreyohanes G, Cunningham V, Kutenplon $\mathrm{D}$, Bouey O. Distance education to prepare nursing faculty in Eritrea: diffusion of an innovative model of midwifery education. J Midwifery Womens Heal. 2007;52(5):e37-e41. doi:10.1016/j.jmwh.2007.07.002.

8. Tagoe M. Students' perceptions on incorporating e learninginto teaching and learning at the university of Ghana. Int J Educ Dev using Inf Commun Technol. 2012;8(1):91-103.

9. Keller C, Cernerud L. Students' Perceptions of E-learning in University Education. J Educ Media. 2002;27(1-2):5567. doi:10.1080/1358165020270105.

10. Mahdizadeh H, Biemans H, Mulder M. Determining factors of the use of E-learning environments by university teachers. Comput Educ. 2008;51(1):142-154. doi:10.1016/j.compedu.2007.04.004.

11. Saadé RG, Nebebe F, Tan W. Viability of the "Technology Acceptance Model" in Multimedia Learning Environments: A Comparative Study. Interdiscip J Knowl Learn Objects. 2007;3:175-184.

12. Zuvic-Butorac M, Rončević N, Nemčanin D, Nebić Z. Blended E-learning in Higher Education: Research on Students' Perspective. Issues Informing Sci Inf Technol. 2011;8:409-429. http://bib.irb.hr/prikazirad?\&amp;lang=en\&amp;rad=513901.

13. Link TM, Marz R. Computer literacy and attitudes towards E-learning among first year medical students. BMC Med Educ. 2006;6:34. doi:10.1186/1472-6920-634.

14. Unnikrishnan B, Kulshrestha V, Saraf A, Agrahari AC, Prakash S, Samantaray L PA. Pattern of computer and internet use among medical students in Coastal South India. South East Asian J Med Educ. 2008;2(2).

15. Bagi J. G and Hashilkar NK. : Blended learning integrating E learning with traditional learning methods in teaching basic medical science. Al Ameen J Med Sci. 2014;7(4):265-269. 


\section{Appendix 1}

\section{Code:}

\section{General information}

1. Gender: male

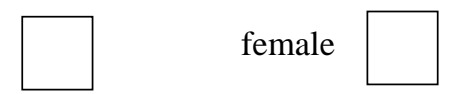

2. Age:

3. Currently in:

\begin{tabular}{|c|c|c|c|}
\hline $1^{\text {st }}$ year & $2^{\text {nd }}$ year & Third year & $4^{\text {th }}$ year \\
\hline & & & \\
\hline
\end{tabular}

\section{Computer and internet use}

4. Do you use the computer?

Yes

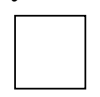

No

5. If yes since how many years have you been using the computer?

\begin{tabular}{|c|c|c|}
\hline Less than 2 years & $2-5$ years & More than 5 years \\
\hline & & \\
\hline
\end{tabular}

6. Do you own a computer/laptop/? Yes

No

7. How often do you use the internet?

\begin{tabular}{|c|c|c|}
\hline$<2 \mathrm{hrs} /$ day & $2-5 \mathrm{hrs} /$ day & $>\quad 5 \mathrm{hrs}$ a day \\
\hline & & \\
\hline
\end{tabular}

8. How often do you use the internet for academic purposes?

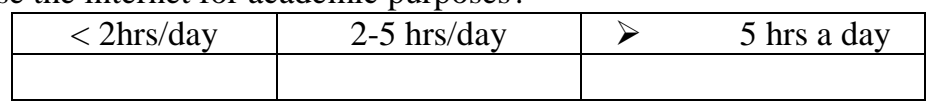

Awareness and understanding of E-learning

9. Are you aware of E-learning? Yes

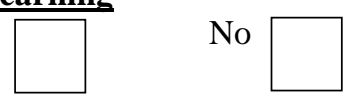

10. What do you understand by e- learning?

11. Which of these do you think can be used as a mode of E-learning?

a. Power point modules

b. Video lectures

c. Internet based learning

d. Intranet based learning

e. Use of CDs for learning

E-Learning comprises all forms of electronic learning: It involves the use of Internet technologies to enhance knowledge and performance. E-learning system offers learners the ability to have control over the content, learning sequence, pace of learning, time, and often media, allowing them to tailor their experience to meet personal learning objectives.

Your opinion on how E-learning will affect the learning process

\begin{tabular}{|l|l|l|l|l|l|} 
& $\begin{array}{c}\text { Strongly } \\
\text { agree (5) }\end{array}$ & $\begin{array}{c}\text { Agree } \\
\text { (4) }\end{array}$ & $\begin{array}{c}\text { Neutral } \\
\text { (3) }\end{array}$ & $\begin{array}{c}\text { Disagree } \\
\text { (2) }\end{array}$ & $\begin{array}{c}\text { Strongly } \\
\text { disagree (1) }\end{array}$ \\
\hline $\begin{array}{l}\text { E-learning system will be } \\
\text { easy to use }\end{array}$ & & & & & \\
\hline E-learning will save time & & & & & \\
\hline It will make learning easier & & & & & \\
\hline $\begin{array}{l}\text { it will make course content } \\
\text { easier to understand }\end{array}$ & & & & & \\
\hline
\end{tabular}




\begin{tabular}{|l|l|l|l|l|l|}
\hline $\begin{array}{l}\text { it will increase my learning } \\
\text { efficiency }\end{array}$ & & & & & \\
\hline $\begin{array}{l}\text { It will give me more } \\
\text { independence }\end{array}$ & & & & & \\
\hline I will be more motivated & & & & & \\
\hline
\end{tabular}

Opinion on incorporation of E-learning into the curriculum

\begin{tabular}{|l|l|l|l|l|l|}
\hline $\begin{array}{l}\text { E-learning should be incorporated } \\
\text { into the medical curriculum }\end{array}$ & & & & \\
\hline $\begin{array}{l}\text { If answer to above question was } \\
\text { strongly agree or agree, which } \\
\text { year/years should it be } \\
\text { incorporated }\end{array}$ & & & & \\
\hline Which year of medical college do & & & \\
you thing E-learning will/would \\
have benefited u most?
\end{tabular}

Perceptions regarding use of internet /web resources for teaching (tick your choice)

\begin{tabular}{|l|c|c|c|c|}
\hline & $\frac{\underline{\text { Fully }}}{\text { online }}$ & $\begin{array}{c}\frac{\text { Web dependent }}{\text { (online participation }} \\
\text { compulsory) }\end{array}$ & $\frac{\frac{\text { Web supplemented }}{\text { (online participation }}}{\text { optional) }}$ & 年 \\
\hline $\begin{array}{l}\text { Teachilly web } \\
\text { should be }\end{array}$ & & & & \\
\hline
\end{tabular}

Any other comments: 